\title{
Essential characteristics of a profession: A historical analysis focusing on the nursing process
}

\author{
Características essenciais de uma profissão: análise histórica \\ com foco no processo de enfermagem \\ Características esenciales de una profesión: análisis histórico \\ con énfasis en el proceso de enfermería
}

How to cite this article:

Benedet SA, Padilha MI, Peres MAA, Bellaguarda MLR. Essential characteristics of a profession: A historical analysis focusing on the nursing process. Rev Esc Enferm USP. 2020;54:e03561. DOI: https://doi.org/10.1590/S1980-220X2018047303561

\section{Silvana Alves Benedet ${ }^{1}$ \\ Maria Itayra Padilha ${ }^{2}$ \\ Maria Angélica de Almeida Peres ${ }^{3}$ \\ Maria Ligia dos Reis Bellaguarda ${ }^{2}$}

${ }^{1}$ Universidade Federal de Santa Catarina, Hospital Universitário, Florianópolis, SC, Brazil.

${ }^{2}$ Universidade Federal de Santa Catarina,

Departamento de Enfermagem, Florianópolis, SC, Brazil.

${ }^{3}$ Universidade Federal do Rio de Janeiro, Escola de Enfermagem Anna

Nery, Rio de Janeiro, Brazil.

\begin{abstract}
Objective: To analyze knowledge/expertise, autonomy and professional status in the ways of practicing nursing in implementation of the Nursing Process in a University Hospital in Southern Brazil. Method: A qualitative socio-historical study using thematic oral history as a method and technique. Data were collected through semistructured interviews with care nurses and professors. The Content Analysis technique was used in the analysis. Results: Fourteen (14) care nurses and professors participated. Knowledge/expertise were pointed out as the main contributions in implementing the Nursing Process. Professional status emerged as recognition of technical and scientific competence of nurses by health staff and users. Autonomy was expressed as being able to decide on their conduct and linked to knowledge, commitment and professional identity. Conclusion: The Nursing Process is a way of exercising the profession based on knowledge and expertise with autonomy, and enables achieving status, reinforcing professional recognition.
\end{abstract}

\section{DESCRIPTORS}

Nursing; Nursing Process; Professional Practice; Professional Competence. 


\section{INTRODUCTION}

Nursing appropriated knowledge related to care during the construction of its history and identity to assert itself as a scientific profession. By institutionalizing nursing as a profession, Florence Nightingale identified the need to base this practice on scientific principles, going beyond organized and practical training. Although the concept of the Nursing Process did not yet exist in the second half of the $19^{\text {th }}$ century, studies state that Florence already emphasized the need for nurses to observe and make judgments about the care provided ${ }^{(1)}$, determining the knowledge and practice of the profession. In a way these determinants can be considered the basis of what would be configured in the future as the nursing process. However, it was not until the 1950s that nursing began to use the Nursing Process, a term which expresses the use of the scientific method in nursing care ${ }^{(2)}$.

The Nursing Process expresses itself as one of the instruments that represents the evolution of nursing as a profession located in the health field, since it goes beyond the fulfillment of tasks and develops a body of knowledge of its own and centralizes its doing in human relationships and in the circumstances in which it is manifested in the context of health/illness ${ }^{(3)}$.

The construction of a body of knowledge has been decisive in achieving professional nursing autonomy. In this sense, the Nursing Process "is a path of autonomy for the profession by representing a care methodology recognized by nurses and allowing them to be closer to users, both at the time of its elaboration and in providing care, constituting its greatest competence"(4).

Sociology of the professions shows two types of professions: consulting professions and academic professions ${ }^{(5)}$. The first profession is one which sells its services to a clientele, is committed to meeting their needs and maintains a direct and continuous relationship with the lay population. In the academic profession, the practitioner's owes reporting their activities to the academic community, and they create and elaborate official knowledge, and apply it to everyday life. From this perspective, nursing was characterized by scholars ${ }^{(3)}$ as a consulting profession, as it maintains a direct and continuous relationship with the lay population, sells its services to this population and the satisfaction of their needs has consequences on the organization of the profession.

This study understands the Nursing Process as a catalyst strategy for consolidating the category's professionalization from the perspective of knowledge/expertise, professional status and autonomy in light of the sociology of professions of Eliot Freidson.

Eliot Freidson lists the following characteristics in determining what an occupation must possess to be considered a profession: possessing a body of knowledge, including expertise; a service focused on the community; autonomy over their own standards of education and training; credentialism; and professional status ${ }^{(5)}$.

Thus, the objective of this study was to analyze the knowledge/expertise, autonomy and professional status in the ways of practicing nursing from implementing the Nursing
Process at the University Hospital of the Universidade Federal de Santa Catarina (HU/UFSC) in the period from 1979 to 2004 . The initial historical period refers to the creation of Ordinance No. 358/79, which appointed the Implementation Committee of the University Hospital of Santa Catarina (CIHUSC), and the cut-off limit to the year of implementing computerization of the Nursing Process encouraged by the publication of the Resolution of the Federal Nursing Council (COFEN) no. 272/2002.

\section{METHOD}

\section{STUDY DESIGN}

A socio-historical study with a qualitative approach based on the New History ${ }^{(6)}$ and the sociology of professions of Eliot Freidson ${ }^{(5)}$, using oral history as the data collection method and technique.

\section{THEORETICAL FRAMEWORK}

Eliot Freidson's work presents the main theoretical elements necessary for the analysis of professions, with its characteristics highlighted in this study being: knowledge/ expertise, autonomy and professional status.

Knowledge/expertise refers to a body of facts which are apparently true, ordered by some abstract ideas or theories: one can find them included in treatises and textbooks, which provide the formal essence from which experts learn in professional schools and which they presumably know after doing $\mathrm{so}^{(5)}$. An expert puts the knowledge into practice. The body of knowledge consists of what the profession knows in detail in the scope of doing, practicing and arguing in defense of this expertise.

Autonomy is considered as proof of the condition of profession. Members of a profession are not controlled by anyone outside of it. This is due to the exceptional level of expertise and knowledge related to the work, the confidence in the work being done and self-regulation, i.e. the profession itself judges whether a behavior is ethical. Autonomy is therefore tested and justified by self-regulation ${ }^{(5)}$.

Professional status is achieved through the protection of an elite society due to the value of this profession. This is ensured by the social and economic influence of this elite. The work performed by professionals is complex and indicates high prestige. Part of the professional and the ideology that surrounds them are historical realizations of the profession status and the social origins of its practitioners. The profession emphasizes its independence, its social and economic individualism, its class dignity and its status. "Final control over one's work is decisive for the status of a profession. This control does not have to be total, but it is essential that it exists over the determination and evaluation of the technical knowledge used at work" ${ }^{(5)}$. In turn, economic and social control is secondary, although it is important ${ }^{(5)}$.

\section{StUdY SCENARIO}

The Professor Polydoro Ernani University Hospital of São Thiago, Universidade Federal de Santa Catarina 
(HU-UFSC), located in Florianópolis, Santa Catarina State, Brazil.

\section{Population}

Fourteen (14) nurses participated in the study, of which eight were assistants from the $\mathrm{HU}$ and six professors from the Nursing Department of UFSC which formed the group of construction, installation and/or implementation of the Nursing Process of the HU-UFSC in the historical period of 1979 to 2004.

The selection criterion was to be a care nurse or nursing professor of the Department of Nursing and to have worked at the HU-UFSC between 1979 to 2004.

\section{DATA COlLECTION}

Thematic Oral History was used with the application of a semi-structured interview script associated with Documentary Research ${ }^{(6)}$. A pre-test interview was conducted in order to verify the adequacy of the Data Collection Instrument. The interviews took place between November 2014 and March 2015, were digitally recorded, transcribed and went through the copydesk process for reducing excesses related to colloquial language and repetitions ${ }^{(7)}$. The documentary sources used were the Basic Nursing Document, which contains the objectives, the philosophy and the entire Methodology of Nursing Care, and the Nursing Care Referential Ambulatory of the HU/UFSC.

\section{DATA ANALYSIS AND PROCESSING}

Content Analysis technique ${ }^{(8)}$ was used to analyze the information following the steps: $1^{\text {st }}$ pre-analysis, characterized by an exhaustive reading of all the interviews and documents; $2^{\text {nd }}$ coding, in which elements were grouped under generic titles and then transformed into subcategories and categories; $3^{\text {rd }}$ categorization, which occurred with the logical inferences of the speech and documents content; $4^{\text {th }}$ interpretation, with the results being discussed in a broader perspective; and finally the $5^{\text {th }}$ stage, in which the synthesis between the research question, the results, the inferences made and the adopted theoretical perspective was elaborated.

\section{ETHICAL ASPECTS}

The interviews were forwarded for validation by the interviewees, who signed the Copyright Cession Term for the main researcher. People who were cited by study participants during the interviews were identified with the letter (\&\&\&), preserving their anonymity. This study evidences the people who participated in the construction of the HU-UFSC Nursing Process, and all participants (the oral sources of this study) authorized their identification, and also gave authorization to identify the institution. The study as a project was submitted and approved by the Ethics Committee on Research with Human Beings of the Universidade Federal de Santa Catarina, under Opinion No. 864.317/2014, in accordance with the requirements of Resolution 466/2012 of the National Health Council.

\section{RESULTS}

The results show knowledge and expertise as the main contributions of the HU/UFSC Nursing Process, with knowledge being essential in its implementation because it is necessary to tirelessly study to evaluate, diagnose, plan and execute nursing care which meets the health needs of users. This fact very forcefully appeared in the narratives.

You need to have scientific knowledge to implement a good nursing process. If there is one thing the patient presents that you don't know yet, you have to go back, look, read. That's what we did, we didn't make a prescription without flipping through the Basic Nursing Document (TSR).

The nurses were able to gain the expertise as the Nursing Process was implemented, as expressed in the following narratives:

The methodology brought much recognition of the nurse's knowledge. I knew some new procedures that doctors didn't know, for example, in family planning, I had a sponge that was placed on the cervix, an idea brought from England. It was very common for medical students to attend my appointments, because they didn't know the approach I was using and wanted to know what it was (EFL).

One of the aspects highlighted in the narratives was the contribution of the HU/UFSC Nursing Process to forming a proper body of knowledge for the profession and the reaffirmation of its role in healthcare. This corpus was formed by implementing the Nursing Process in that historical period in each of the stages of the implemented process model (history, prescription and evolution), which was based on a Nursing Theory.

All the material produced by the nursing professors and care nurses to enable implementing the Nursing Process were compiled into a single document called Basic Nursing Documents, used to date, including nursing students, contributing to this body of knowledge.

Our books, the documents which were so well written by the teachers and are there today for those who want to see it, are still current today. Students are amazed when they research those documents (TSR).

Knowledge acquisition was stimulated by implementing the Nursing Process, and also manifested itself as a way for nurses to reflect on the care provided, to plan it so that it was not a mere repetition of tasks.

A scientific work is made from the observation of reality, it has to have a plan of action. If you have to do research, for example, why not do nursing care? You have to know this patient, know their life history, illness history, family history, beliefs, seeing the patient as a whole. Then make the action plan based on the nursing history. This observation and analysis has to be recorded. Registration is done through the evolution of nursing. Evolution will give you an analysis after, to see what you will do (MCG).

The knowledge provided by implementing the Nursing Process stimulated the search and development of technologies which did not exist in the hospital in the historical period studied, as shown in the following narrative: 
Before retiring, I was using a protocol at the outpatient clinic which is not a nursing theory, but proposes the seven care actions for diabetic patients. This protocol implemented self-care and was within the proposals of the International Diabetes $A s-$ sociation. I thought it was appropriate because it represented something new, although it was not a nursing theory. For care to happen effectively the team has to be committed to this care (RBS).

The knowledge fostered by implementing the Nursing Process in addition to being consumed in the work process itself, generated scientific production, represented here by the publication of books together with the nursing professors, as well as the creation of research groups whose recognition went beyond the study hospital.

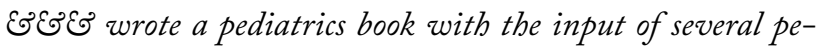
diatric nurses from $H U$. We were always studying. Because we are recognized for knowledge and the Nursing Process makes us study more (RBS).

The professional status was manifested in the narratives of the study participants as the recognition of knowledge and the nurse performing with professional competence, considering the importance of their share in healthcare from implementing the Nursing Process. In this sense, we can identify acknowledgment of the competent doing of nurses of the study hospital by health professionals outside the hospital, as exemplified in the speech below:

A nurse from Spain came to know our work. She stayed with me a few days, then said: "I'm thinking about how I'm going to implement this in Spain because there is no demand there, people don't want nursing consultation. I see you have a schedule and I go there and nobody wants it. She was thinking what strategies to use to deploy the consultation there (SVSS).

In other narratives the professional status appears as recognition by the nurses themselves, configuring itself in many ways as high professional self-esteem. For example:

I was pleased to be called a nurse. She made a point of being called "Nurse Rita." So we had that, to be recognized by the profession. I had to have this commitment to the profession and the Nursing Process rescues it (RBS).

Recognition of the technical and scientific competence of nurses as a contribution to the Nursing Process of other health team professionals who worked in the hospital in the historical period studied is also highlighted.

The doctors didn't visit without first looking at the evolution of the nurse, which is what happens today. Many times a doctor or nutritionist would ask, "Hasn't the nursing evolution been done yet?" They began to feel their importance, as they often had much more data on nursing evolution than in theirs, as they didn't spend 24 hours with the patient (TSR).

The recognition of knowledge and doing of nurses by users was also highlight, configuring as professional status. The recognition was due to the quality of nursing care provided; quality closely linked to the implementation of the Nursing Process.
We received recognition from the client, family and other professionals. Nursing was very recognized from the clients' statements! The organization of everything related to nursing, including the Nursing Process, bighlighted it (LH).

Regarding the autonomy partly conferred by the Nursing Process implemented in the studied hospital, the oral sources of this study characterize it as a very consistent subcategory. The autonomy gained in the studied context refers to the decision-making about the specific conduct in healthcare compared to the other professionals in the hospital in that historical period.

A great achievement was the fact that we can have a cervical cancer screening test. We talked to the pathologist who read the slides, I don't remember his name, we talked about this distress that we couldn't sign the requisitions. Then I started making culture, bacterioscopy, gonococcus requisitions (EFL).

Autonomy and knowledge are closely associated in some narratives, designing a complex of responsibilities and characterizing the Nurse. This is evidenced in decision-making, which makes doing and knowing more visible to the population served and highlights the nurse as an active professional and belonging to the health team, with well-defined conduct and knowledge. In this way, professionalism is denoted and strengthened, expanding professional status, as noted below:

Because I don't know how to be a nurse without the nursing process, without the autonomy that the process gives me, that all this knowledge gives me. The nursing process gives me security to provide patient care, discuss with other professionals the care provided, gives me security to position myself as a nurse (TSR).

The definition of the nurse's role was a widely-discussed aspect of the profession in the historical period to which this study refers, and the implementation of the Nursing Process brought practical support to this discussion, as it enabled characterizing nursing actions from this professional as being specific. The autonomy conferred by the Nursing Process was also expressed in the narratives as professional commitment.

Nursing here had more autonomy, considered that the center of care was the client, not the medical order. Even after, when I did my thesis, I was able to deconstruct the organization chart and make a design of how all areas of the hospital are in relation to the client (MAS).

The implementation of the Nursing Process in this study proposed nursing care planning based on user needs, seeking solutions to their concrete problems. It was essential that the nurses had professional and ethical commitment and were genuinely concerned with the problems of individuals for this to happen, in addition to the use of science and the construction of a body of knowledge.

\section{DISCUSSION}

The discussion based on the narratives of the study participants points to an important influence of implementing the Nursing Process on the development of the profession, considering the need to form a body of knowledge of its own, determining the expertise. This corpus includes both practical knowledge and knowledge acquired through scientific 
studies and research. Such knowledge is strongly determined and stimulated by implementing the Nursing Process, and formed the solid foundations of nursing professionals; a fact which ensured the quality and safety of the services provided to the population.

The knowledge/expertise emerging in this study relates to the studied historical period. It is important to highlight the innovative and pioneering work of nurses, since the implementation of the Nursing Process in health institutions was quite incipient in the country within that historical period. The best known and most publicized publication (because it is a book) by the pioneer in this study area of Brazilian nursing, Professor Wanda de Aguiar Horta, occurred in 1979, which was one year before the University Hospital opened. Nurses did not know nursing theories or the Nursing Process, so there was a need for intensive training with newly hired nurses on the nursing theory chosen as an argument for the nursing process, which required effort, work and boldness on the part of nurses.

The Nursing Process is the work method used in the nursing area which allows logical analysis and analytical reasoning through research, as well as the development and implementation of care which involve the use of techniques and interpersonal relationships, with the latter being mediated by communication ${ }^{(9)}$. Thus, in this study it was found that the HU/UFSC fulfilled the objective of the Nursing Process to implement safe care with minimal complications in order to facilitate user adaptation and recovery.

Although the importance of adopting the Nursing Process in its work process was consensual in the Brazilian nursing context, the publications of the 1970s and 1980s refer to reports of professors' experience in teaching hospi$\operatorname{tals}^{(10)}$ and show that the experiences of applying the Nursing Process were linked to academic experiences, pointing to the need to encourage implementation in health institutions. At the same time, there was a movement in the country to validate this work instrument by category, which culminated in the publication of Law No. 7.498, of June 25, 1986, regulating nursing prescription and consultation as exclusive attributions of nurses. This law meant an important advance in recognizing the nurse's role and in defining nursing assistant and technician's attributes ${ }^{(11)}$, constituting a legal framework which legitimized the political and professional bases of nursing in the hospital. The nursing professional group participating in this study obtained legal support and an ethical obligation to use the Systematization of Care, and from this the Nursing Process to guide their practice with scientificity, guaranteeing more safety to users.

Implementation of the Nursing Process based on generated knowledge enabled individualized nursing care, configuring the care ideal defended by the Nursing Directorate of HU/UFSC since its implementation. Considering the ethical responsibility embedded in the application of the Nursing Process, the most important attitude of a professional is the feeling of responsibility regarding the integrity of specialized techniques, which is achieved by prolonged training ${ }^{(5)}$. The most important activity linked to this responsibility is manifested by following standards of conduct, which is related to the integrity of practice and its consequences for the user.

The need for expertise in a profession as evidenced by society makes it an autonomous profession ${ }^{(5)}$. However, there is a relativization in the autonomous practice of the professional nurse in acting as a liaison figure in the multidisciplinary team, constantly dialoguing with all other professionals, being the only professional continuously present with patients. And yet, like other health professionals, nursing needs to be resolute, since its object of work is the human being, the community. Nurses are autonomous professionals, and there is a relativization of this practice within this autonomy. As a member of a team, the nurse does not work in isolation or make decisions outside the care context in which patients find themselves.

The results show that there was recognition of the importance of nursing care to users, the health team and nursing itself, which is understood as professional status and conditions the relevance and empowerment of a specific doing of a profession, certified by legislation and ethics, and accepted by society as being of indispensable utility for their well-being ${ }^{(4)}$. On this recognition, the formal status of a profession reflects its license to control work, and is guaranteed by society ${ }^{(5)}$.

In this perspective, when the nurses of the HU/UFSC were using the Nursing Process, they imprinted their clinical reasoning on their care to prescribe, perform and evaluate care, which gave rise to the value of Nursing, its responsibility, importance and credibility which must flow from within the profession, from the attributes of professional members and peers.

The body of knowledge that was historically constituted through implementing the Nursing Process in the studied scenario enabled conquering the social space of nursing in the context of the multiprofessional team. Research conducted with nurses identified that the Nursing Process is conceived as an ideal instrument for care management and for the social recognition of the profession, as it facilitates the scaling of human resources and promotes continuing education ${ }^{(12)}$.

Autonomy is a characteristic which appears in this study as being achieved through implementing the Nursing Process; it presents in relation to health professionals as nurses meet the established care goals, using knowledge and skills of the profession, evaluating the users' needs, communicating concerns and priorities and coordinating the resources of the multidisciplinary team ${ }^{(13)}$.

Nursing defined its concepts about health care in its practice at the $H U$, consolidating the Nursing Process and its relationship with professional autonomy, which gave it security in planning, executing and evaluating nursing behaviors, resulting in the individualization of care, visibility and autonomy for nurses ${ }^{(14)}$.

The Nursing Process confers professional autonomy for nurses, and it is essential that all nursing staff use this work methodology ${ }^{(15)}$. Such autonomy is achieved as it provides the theoretical support and security in decision-making 
in view of the user, thus bringing greater visibility to the profession ${ }^{(16)}$.

The specific knowledge of nursing provided by the Nursing Process enabled the necessary autonomy for nurses to perform their work efficiently, giving them professional appreciation and positive results in the care provided, culminating in professional status. The initiative to assume behaviors, attitudes, and attributes of professional autonomy, "is closely related to the knowledge that the professional has, as this confirms the certainty that nurses are acting in the most correct and appropriate way" ${ }^{\prime 17)}$. Thus, the Nursing Process contributed to consolidating the professional autonomy of nurses in the HU/UFSC, as it revealed their doing, which implied visibility of the profession and therefore contributed to defining their role in healthcare in the institution.

\section{CONCLUSION}

The development of the Nursing Process is configured as assistive technology which contributes to evolving nursing as a profession, primarily focused on understanding the comprehensiveness of the human being, supported by reflection on its practice. The Nursing Process meant the construction of professional identity, differentiating it from other health professions, as it marked a space as a consultation profession. It is undeniable that the practice of the Nursing Process has enabled building and using a body of nursing knowledge, which constitutes as expertise; an aspect which contributes to an independent professional practice, and an essential condition for forming professional identity. This autonomy was mainly expressed in this study as the power to decide on their conduct in user care and was linked to knowledge, commitment and professional identity.

The implementation of the Nursing Process evidenced in this study was a way to practice the profession based on knowledge and expertise with autonomy; something the profession has been developing in recent decades. Such conditions enabled attaining status, reinforcing nurses' professional identity within society.

\section{RESUMO}

Objetivo: Analisar o conhecimento/expertise, a autonomia e o status profissional nos modos de exercer a enfermagem na implementação do Processo de Enfermagem em um Hospital Universitário no Sul do Brasil. Método: Pesquisa sócio-histórica, de abordagem qualitativa, utilizando a história oral temática como método e técnica. A coleta de dados se deu mediante entrevista semiestruturada com enfermeiros assistenciais e docentes. $\mathrm{Na}$ análise utilizou-se da técnica de Análise do Conteúdo. Resultados: Participaram 14 enfermeiros assistenciais e docentes. O conhecimento/expertise foram apontados como as principais contribuições da implementação do Processo de Enfermagem. O status profissional emergiu como reconhecimento da competência técnica e científica do enfermeiro pela equipe de saúde e usuários. A autonomia expressou-se como poder decidir sobre sua conduta e atrelada ao conhecimento, compromisso e identidade profissional. Conclusão: O Processo de Enfermagem é um modo de exercer a profissão pautado no conhecimento e na expertise, com autonomia, e possibilita o alcance do status, reforçando o reconhecimento profissional.

\section{DESCRITORES}

Enfermagem; Processo de Enfermagem; Prática Profissional; Competência Profissional.

\section{RESUMEN}

Objetivo: Analizar el conocimiento/expertise, la autonomía y el status profesional en los modos de ejercer la enfermería en la implantación del Proceso de Enfermería en un Hospital Universitario del Sur de Brasil. Método: Investigación socio-histórica, de abordaje cualitativo, utilizando la historia oral temática como método y técnica. Se hizo la recolección de datos mediante entrevista semiestructurada con enfermeros asistenciales y docentes. En el análisis, se empleó la técnica de Análisis de Contenido. Resultados: Participaron 14 enfermeros asistenciales y docentes. El conocimiento/expertise fueron señalados como los principales aportes de la implantación del Proceso de Enfermería. El status profesional emergió como reconocimiento de la competencia técnica y científica del enfermero por el equipo sanitario y usuarios. La autonomía se expresó como poder decidir acerca de la conducta y vinculada al conocimiento, compromiso e identidad profesional. Conclusión: E1 Proceso de Enfermería es un modo de ejercer la profesión basado en el conocimiento y la expertise, con autonomía, y posibilita el alcance del status, reforzando el reconocimiento profesional.

\section{DESCRIPTORES}

Enfermería; Proceso de Enfermería; Práctica Profesional; Competencia Profesional.

\section{REFERENCES}

1. Fraga TF, Matos E, Costa R, Salum NC, Maliska ICA. The nursing process in an obstetric center: perspective of nurses. Texto Contexto Enferm. 2018;27(3):e4600016. DOI: http://dx.doi.org/10.1590/0104-070720180004600016

2. Smith ME, Parker M. Nursing theories and nursing practice. Philadelphia: Davis; 2015.

3. Bellaguarda MLR, Padilha MI, Peres MAA, Paim L. The nursing profession: its status: is the question. Rev Enferm UERJ. $2016 ; 24(2): e 8591$. DOI: https://doi.org/10.12957/reuerj.2016.8591

4. Catafesta G, Klein DP, Canever BP, Lazzari DD, Silva EF. Consulta de enfermagem ginecológica na estratégia saúde da família. Arq Ciênc Saúde. 2015;22(1):85-90. DOI: https://doi.org/10.17696/2318-3691.22.1.2015.32

5. Freidson E. Profissão médica: um estudo de sociologia do conhecimento aplicado. São Paulo: UNESP; 2009.

6. Padilha MI, Bellaguarda MLR, Nelson S, Maia ARG, Costa R. The use of sources in historical research. Texto Contexto Enferm. 2017; 26(4):e2760017. DOI: http://dx.doi.org/10.1590/0104-07072017002760017

7. Alberti V. Histórias dentro da história. In: Pinsky CB. Fontes históricas. São Paulo: Contexto; 2010. p. 155-202.

8. Minayo MCS, Assis SG, Souza ER. Avaliação por triangulação de métodos. Rio de Janeiro: FIOCRUZ; 2006. 
9. Huitzi-Egilegor JX, Elorza-Puyadena MI, Urkia-Etxabe JM, Asurabarrena-Iraola C. Implementation of nursing process in a health area: models and assessment structures used. Rev Latino Am Enfermagem. 2014;22(5):772-7. DOI: http://dx.doi.org/10.1590/0104-1169.3612.2479

10. Trindade LRT, Ferreira AM, Silveira A, Rocha EN. Processo de enfermagem: desafios e estratégias para sua implementação sob a ótica de enfermeiros. Saúde (Sta Maria) [Internet]. 2016 [citado 2018 ago. 20];42(1):75-82. Disponível em: https://periodicos.ufsm.br/revistasaude/ article/viewFile/19805/pdf

11. Kletemberg DF. O fascínio da ciência na área da saúde (1960-1990). In: Padilha MI, Borenstein MS, Santos I. Enfermagem: história de uma profissão. São Caetano do Sul: Difusão; 2015. p. 295-334.

12. Casafus KCU, Dell'Acqua MCQ, Bocchi SCM. Entre o êxito e a frustração com a Sistematização da Assistência de Enfermagem. Esc Anna Nery. 2013;17(2):113-321. DOI: http://dx.doi.org/10.1590/S1414-81452013000200016

13. Kletemberg DF, Padilha MI. Gerontological nursing: the production of knowledge in the profession (1970-1996). Rev Gaúcha Enferm (Online). 2013; 34(1):86-93. DOI: http://dx.doi.org/10.1590/S1983-14472013000100011

14. Benedet S, Padilha MI, Gelbke FL, Bellaguarda MLR. The model professionalism in the implementation of the Nursing Process (1979-2004). Rev Bras Enferm. 2018;71(4):1907-14. DOI: http://dx.doi.org/10.1590/0034-7167-2017-0226

15. Medeiros AL, Santos SR, Cabral RWL. Sistematização da assistência de enfermagem na perspectiva dos enfermeiros: uma abordagem metodológica na teoria fundamentada. Rev Gaúcha Enferm (Online). 2012;33(3):174-81. DOI: http://dx.doi.org/10.1590/S198314472012000300023

16. Menezes SRT, Priel MR, Pereira LL. Nurses' autonomy and vulnerability in the Nursing Assistance Systematization practice. Rev Esc Enferm USP. 2011;45(4):953-58. DOI: http://dx.doi.org/10.1590/S0080-62342011000400023

17. Silva EGC, Oliveira VC, Neves GBC, Guimarães TMR. Nurses' knowledge about Nursing Care Systematization: from theory to practice. Rev Esc Enferm USP. 2011;45(6):1380-86. DOI: http://dx.doi.org/10.1590/S0080-62342011000600015 